Designing administrative reforms for maintaining trust

Lars Klemsdal $^{\text {a* }}$ and Lars Erik Kjekshus ${ }^{\mathrm{a}}$

${ }^{a}$ Department Department of Sociology and Human Geography, University of Oslo, Norway

* Postboks 1096 Blindern, 0317 Oslo, Norway, lars.klemsdal@ @osgeo.uio.no

Lars Klemsdal \& Lars Erik Kjekshus (2019) Designing Administrative Reforms for Maintaining Trust, International Journal of Public

Administration, DOI: 10.1080/01900692.2019.1694540 


\section{Designing administrative reforms for maintaining trust}

This paper explores how to maintain trust while implementing administrative reforms. The contribution is to show how trust can be enhanced through the design of reform plans. Contrary to the position that favours trust-based management over authority-based management, this paper favours a relational understanding of managing trust, which involves balancing authority and openness towards employees' involvement. Moreover, different situations will require different balance points between the two dimensions. The notion of 'minimal critical specification design' is advanced as a sensitizing conceptualisation of optimal reform designs for maintaining trust during implementation. The argument is illustrated through the case of a large administrative reform within the Norwegian welfare sector.

Keywords: trust, administrative reform, reform design, public management

\section{Introduction}

It is well established that trust is important to effective and efficient governance and management within the public sector (Axelrod, 1984; Bianco, 1994; Blumberg, 1989; Brown, 1994; N Luhmann, 1988; Miller, 1992; Powell, 1990, 1996; Putnam, 1993; Sitkin \& Roth, 1993). As Powell puts it, trust is "a remarkably efficient lubricant to economic exchange [that] reduces complex realities far more quickly and economically than prediction, authority, or bargaining” (1990, p. 305). Recently, the notion of 'trust-reforms' has become increasingly popular as a reference for good public management, particularly in the Nordic context (Andreasson, 2017). In the literature, trust-based management and governance in terms of involvement and autonomy are advanced as important to higher job satisfaction, loyalty and productivity (Colquitt, Scott, \& LePine, 2007; Deng \& Wang, 2009; Dirks \& Ferrin, 2001; Lau, Lam, \& Wen, 2014). In particular, maintaining trust is critical during public sector reforms (Knack \& Zak, 2003; Rothstein, 2011). Reforms often come as a response to seemingly unsolvable wicked issues through coordination and cost-control mechanisms, and these reforms are implemented by organisations characterised by complex target structures, which are often the sources of the wicked issues (Christensen, Lise Fimreite, 
\& Lægreid, 2007). Thus, implementation of reforms is seldom straightforward. Rather, it requires extensive adaptations and negotiations in order to succeed, and trust plays a decisive role to avoid employee resistance (Feldheim, 2007). In addition, reforms and particularly structural reforms have a significant negative effect on employee trust towards management (Feldheim, 2007; Morgan \& Zeffane, 2003). Given that organisational reform is prevalent as an important measure for improving public sector performance (Caiden, 1999), it is important to gain insights into how to manage the implementation of administrative reforms in ways that maintain or enhance trust between management and employees. This paper contributes to knowledge on this central issue by addressing a largely ignored aspect of this problem namely the question, how can trust be maintained through the design of reform plans?

This paper answers this question by presenting a conceptual framework for how to design administrative reforms in order to maintain trust during implementation. The conceptual framework is developed in four steps: First, the concept of trust and its relation to management are theoretically elaborated. A conceptual model of trust as multidimensional, relational and context dependent is developed, which is to be maintained and enhanced at the crossroads between confidence and uncertainty. Second, this understanding of trust is translated into a practical heuristic for maintaining trust during the implementation of public reforms by balancing openness in terms of employee participation in enacting reforms at the local level and the exercise of authority in terms of managerial instruction of what the reform is about. The balance point varies according to variations in situational contingencies; it must also be perceived as an ongoing process that can never probably be settled (as with any kind of balancing act that requires proactive movement to succeed).

Third, how this dynamic is played is out is illustrated by experiences from the implementation of a large administrative reform within Norwegian welfare services. Fourth, the 'minimal critical specification design' concept (Herbst, 1974) is highlighted as a design 
principle for administrative reform that can accommodate the balance between openness and authority during implementation processes.

\section{A Dynamic and Relational Concept of Trust}

This analysis hinges on a multidimensional, dynamic and relational understanding of trust, which is perceived as an emergent property of enactment of relations rather than as a discrete individual psychological entity or state (Kahneman, Knetsch, \& Thaler, 1986; Morgan \& Zeffane, 2003; T. R. Tyler, \& Dawes, R., 1993; T. R. Tyler \& Lind, 1992). In this vein, Elster (2007) defines trust as reflective action - the outcome is dependent on actions in several returns, but also the avoidance of action even when the other provokes it:

To trust someone is to lower one's guard, to refrain from taking precautions against an interaction partner, even when the other, because of opportunism or incompetence, could act in a way that might seem to justify precautions (Elster 2007, p. 344).

This means that trust is a phenomenon that cannot be achieved by direct action. A person cannot decide to be trustworthy, but she can decide to lower her guard, and thereby invite or create a situation where the other party is allowed do demonstrate trustworthiness. Thus, trust mutually evolves between these two individuals. This means that trust thrives on risk or vulnerability; in order for trust to be at play, the participants have to take risk or put themselves in a vulnerable situation. However, the same goes for the related but not synonymous notion of unpredictability. If someone could fully predict how another person would react or act towards them, trusting them would not be an issue. As Lewis and Weigart (1985, p. 969) put it: "trust begins where prediction ends." Thus, taken together, this contingency of trust can be conceptualised as 'uncertainty'. In order for trust to be at play 
between parties and evolve, there must be a degree of uncertainty involved between the parties, providing a need for trust to evolve. However, this opportunity for trust grounded in uncertainty is somewhat paradoxical in nature, as the greater the uncertainty (either in terms of risk and/or unpredictability), the more trust is needed but also the harder it is to maintain and enhance trust (Sørensen, Hasle, \& Pejtersen, 2011). Thus, trust is seldom based on blind faith or a general principle; instead, it rests on some kind of calculation with reference to both consequences and expectancies (Axelrod, 1984; Williamson, 1993). This will be characterized as the confidence-dimension of trust processes. An important foundation for this assessment of confidence is the mutuality or reciprocity that follows from the other lowering their guard and taking risk towards another person. This creates a mutual dependency, which is further underpinned by mutual commitments based on what Luhmann $(1979$, p. 41$)$ characterises as 'the law of meeting again'. A further foundation is the person's interpretations of the other's qualities, signalled in behaviours that are allowed to unfold in the relational process (Clark \& Payne, 1997). In working life contexts, signals of such confidence-inducing qualities will be interpreted from different sources, such as policies, strategies and systems (Sørensen et al., 2011), which provide some kind of predictability and closure in the situation. In this way, trust between parties unfolds in a two dimensional space of on the one hand uncertainty, constituting a need for trust, and on the other confidence, constituting a basis for trust.

Note that the variations in trust are also two-dimensional within this space. As Luhmann (1979, p. 79) points out, trust and distrust are not opposites on a scale. A reduction in the space for trust — for instance due to reduced complexity and increased predictability or due to other measures, such as formal standard operational procedures — does not itself lead to distrust, only to the reduction in the need for (and thus space for) trust to evolve (cf. for instance duGay, 2000). In such cases, the level of mutual confidence reduces all uncertainty and thus replaces the need for processes of trust between the parties. 
This multidimensional and seemingly paradoxical nature of trust suggests that trust as a social process (rather than as individual assessments of others) can be maintained and enhanced in situations that must have space for uncertainty to unfold and at the same time contain reasons for confidence, providing a degree of closure. However, the optimal balance in this mix will vary depending on situational contingencies, which can be further elaborated by considering the relationship between management and trust.

\section{Management and Trust, Depending on the Situation}

This two-dimensional and relational understanding of trust will now be translated into measures for how situations of trust can be created and managed. Traditionally, management is understood as exercised in the tension between trust and authority (Sørhaug, 2004). In this view, authority is what is associated with command, control and instruction - the use of organisational instruments, such as formal structure, incentives, contracts, reporting and control in order to force others do something they would not otherwise have done, as Robert Dahl (1957) would have put it. Trust, in contrast, is often believed to be established through relational management, which is leading through emergent social relationship. Here, management is dependent on reciprocity between the person who manages and the one who is affected - it is management based on trust. Several studies study the feeling of being trusted, (Deng \& Wang, 2009; Dirks \& Ferrin, 2001; Lau et al., 2014), especially the negative effect of monitoring and controlling the feeling of trust (Bernstrøm \& Svare, 2017; Falk \& Kosfeld, 2006; Westin, 1992). These approaches, thus, tend to contrast authority-based and trust-based management, something that is also mirrored in recent popular notions, such as 'trustreforms', which refers to the need to reduce authority-based governance and management forms in order to increase the basis of trust in public management (Andreasson, 2017). However, this distinction ignores the relational and indirect character of trust, just 
conceptualised, where trust presupposes a balance of mutual uncertainty and confidence. But it also fails to account for the contextual contingencies conditioning the optimal balance point between these dimensions of trust. The reasons for having confidence in the other as well as the kind of uncertainty necessary for trust to emerge will vary dependent on the characteristics of the situation and may imply both the exercise of authority as well as an openness towards the other (lowering of guards). In other words, the mix between uncertainty and confidence, translated into management measures, can be managed through balancing authority and openness in relation to the situation at hand. To make this point more easily applicable, a heuristic developed by Grint (2005) is adapted, which distinguishes between various accounts or definitions of situations in which different kinds of approaches to the enactment of authority are considered appropriate. Subsequently, the dynamics of trust varies according to what is considered the appropriate type of situation.

In tame problem situations, what Grint (2005) characterises as management, is considered the appropriate mode of authority. The optimal conditions (mix of uncertainty and confidence) for trust to evolve can be found in the balance between managers envisioning correct, or referring to, standard operating procedures and the employees being allowed to follow the procedures and apply them to the situations at hand without supervision. In this way, managerial instructions (i.e., authority) must be considered part of the framework wherein trust evolves and as a basis for confidence. However, at the same time, in these situations, the mutual uncertainty tends to be so low and the confidence in what to expect of the other so high that trust is not an issue. There is no need for trust; it is all mutual confidence. But the authority measures can also be exercised in ways that signal a lack of confidence in the other party - through excessive control measures for instance - that may lead to a process of escalating distrust. 
In situations defined as 'critical' or 'crises', what Grint (2005) calls 'command' is considered the appropriate mode of authority. Trust evolves around the uncertainty related to the fatality of potential consequences. Confidence is based on the manager providing adequate instructions through swift decision making and the effective execution of orders by the employees. Finally, in situations defined as consisting of 'wicked problems', what Grint (2005) calls 'leadership' is considered the appropriate mode of authority. Trust evolves when the leader displays openness about what is the right thing to do and invites broad participation from the followers in problem solving, and the followers respond by participating constructively in the process of searching for answers (not waiting for commands or asking for procedures). This means for instance that a leadership approach in situations that are generally accounted for as crises will not enhance mutual trust between the parties but rather distrust. A command or procedural approach to situations generally characterised by wicked problems and ambiguity will not invite trust relations to evolve but rather relations of distrust. It is important to point out that these distinctions must be treated as heuristics to sensitize (Blumer, 1954) us towards consequences of contextual variations in the conditions for confidence and uncertainty. In practical real life situations, crisis situations will often contain wicked problems; moreover, the success of handling such situations depends on the quality of the procedures and routines available to the participants. There may often be conflicting views and negotiations about whether an operational situation should be defined or treated as a tame, wicked or crisis situation (Grint, 2005), which is the core problem while maintaining trust in management.

\section{Trust during the Implementation of Administrative Reforms}

Thus, trust is a delicate relational phenomenon that is continuously in process between individual actors or groups of actors. It unfolds in spaces that must contain uncertainty (both 
in terms of risks and unpredictability) in order for trust to be an issue between the parties as well as confidence that is built on the interpretations and assessments of the signalled qualities of the other (in terms of actions and strategies). This constitutive mix of trust processes can be managed by balancing authority measures and an openness towards employee involvement, which will vary according to the traits of the situation at hand. Applied to administrative reforms within the public sector, the situations that such reforms address and are designed for may vary within this continuum of situations. This means that the balance between authority and openness will also have to be deliberately various in order to create optimal processes for maintaining trust. In other words, given the nature of trust as just described, it is possible to design or create within the parameters of authority and openness rather specific spaces where trust can evolve (by mixing conditions of uncertainty and confidence) during the implementation of administrative reforms.

\section{Method}

How to maintain and enhance trust relations through the design of reform plans will now be further theorised by analysing the implementation of a large administrative reform of the Norwegian welfare services, executed from 2005 to 2011. The first author was involved as a researcher in the official evaluation of the implementation of the reform and published various papers on different aspects of the reform. These published papers will be drawn on, as well as the collected empirical material from the evaluation. The evaluation was conducted by extensive document studies, interviews with elite decision makers, such as politicians and top managers (Christensen, Fimreite, \& Lægreid, 2014), and a comparative study of the experience of 10 frontline organisations with implementing the reform at the operational level (Fossest $\varnothing 1$, Breit, Andreassen \& Klemsdal, 2015). The evaluation was based on interviews with managers (between one and five, depending on the office size), union representatives and 
frontline employees from each of the ten frontline organisations. Each frontline organisation was visited three times (once per year), and approximately ten people were interviewed each time. Thus, the interview material comprises about 30 to 40 interviews from each front line organisation and about 350 interviews in total. The interviews were supplemented by observations of meetings and strategic documents, such as organisation charts, planning documents and activity reports. Overall, this comprises a vast amount of empirical material, which has also been utilised and reported in previous studies (Andreassen and Fossestøl 2009, 2011, 2014; Andreassen, Fossestøl and Klemsdal, 2011; Alm Andreassen 2012; Fossest $\varnothing 1$ et al, 2015, Klemsdal, 2009).

The issue of trust has not been thematised in earlier publications on this reform and was neither thematised during interviews with managers and employees. Thus, the original contribution in this paper is to extrapolate implications from studies of other research problems for understanding how trust might be enhanced through the design of reform plans, based on the operationalisation of the concept of trust in management outlined above. Thus the case analysis does not provide clear conclusions on the quality of the trust relations in this particular case. The purpose of the case analysis is to illustrate and concretise the theoretically developed conceptual framework.

\section{Case: The Administrative Reform of the Norwegian Welfare Services}

The Norwegian welfare sector went through a major administrative reform between 2005 and 2011, which aimed at solving the coordination problems within the sector. The general reform strategy involved a merger of the previously separate state-governed local employment and national insurance administrations and the municipal social service offices into new frontline services, so-called one-stop shops (Christensen et al., 2014). Four hundred and fifty-six onestop shops had been established by the end of 2010, covering every Norwegian municipality 
and ranging from five to 100 employees. The official aim of the merger was to create one wholly integrated local service that could meet all of the needs of users of welfare services at one desk, with the ultimate aim of more effectively assisting the users with achieving a selfsubsistent work life (St.prp., 46 2004-2005). Ideally, this would mean that the clients' interactions with the new integrated welfare service should happen through as few people as possible, preferably through one contact person, who would enact a more generalist role as a service provider. Ultimately, the goal of the reform was to provide an institutional change in the way welfare services were provided - from being oriented to maintain the rights of the clients to being oriented towards supporting them according to their needs. The new welfare agency was expected to take a more proactive turn towards facilitating the clients' process of getting back into a working life (St.prp., 46 2004-2005). The reform can be seen as a 'hole government' initiative that was intended to increase the capacity of government to address 'wicked problems' cutting across existing policy areas and to improve vertical and horizontal coordination in the fields of policy and implementation (Christensen et al., 2007).

The implementation of the reform can be divided into two phases. The first was the socalled organisational reform, initiated in 2005/2006. The second was the so called contentreform, initiated in 2008/2009. The two reform phases can be characterised as showing postNPM and NPM traits, respectively (Christensen \& Lægreid, 2013) — that is, from aiming towards cross-functional integration in order to solve wicked issues in the first phase towards specialisation based on a functional division of work. The two reform phases, thus, promoted different organisational designs. However, the two phases of the reform can also be distinguished by employing two different ways of designing the reform plans, which will be central to this discussion. Even though the organisation design and the reform plan designs can be clearly associated, the point of this paper is to treat the latter as loosely coupled to the former. 


\section{Different Reform Plan Designs}

The two phases of the reform displays different traits of designing reform plans. In the first phase, few instructions were provided by the central authorities. Rather, the local managers and employees were invited to participate in processes of developing local solutions to what was the best way of organizing the local one stop shop, through planning and adjustments during implementation of the local plans, according to their specific experiences and knowledge of their own local situational contingencies. These local contingencies included such factors as the client portfolio, task load and profile and the size of the shop in terms of professional employees. But they also included even more specific traits, such as the competency and ability of the employees, the competency profiles of the individuals and the constellations of employees. Initially, this resulted in the development of a range of local designs spanning from specialised offices maintaining the former division of work between the three former services (weak integration models) to so-called generalist designs, in which all of the professionals were expected to handle all sorts of clients with all sorts of service requests with all available means and measures (strong integration models) (Fossestøl et al., 2015; Klemsdal, 2009).

The second phase, however, was characterised by more specific instructions about how to perform tasks, with consequences for the local organisation of task performance at the shops. The content reform introduced, for instance, new legislation and social security funding, which divided and sorted the clients into new categories that partly cut across the former division of services. In addition, a more detailed set of performance goals (MBO) was introduced, specifying 50 performance goals for the local one stop shop to deliver on (Andreassen et al., 2011; Klemsdal, 2011). This resulted in increased isomorphism among the 
local shops, tending towards increased specialisations and a division of work among the employees along the lines of the NPM reforms (cf Christensen and Lægreid, 2013).

Thus, while the design of the reform plans and the management of the implementation process in the first phase can be characterised as low on authority and high on openness, the second phase can be characterised as being high on authority and low on openness. Next, the paper will explore the ground level of the one stop shops, where the reform was enacted, and explore how the local managers and employees experienced the different phases. Then, it will make some suggestions in terms of how to enhance and maintain trust during the implementation of administrative reforms.

\section{The Responses of the Frontline Managers and Employees}

The new local one stop shops are faced with an extensive mission. They serve a range of clients, from drug addicts to people with a wide range of disabilities, as well as people suffering from poverty and people in between jobs who need standard employment services. These clients also have various service needs, ranging from financial support to assistance in managing their problems in getting back to work — be it physically, mentally, or in terms of competency. This also mean that the one stop shop has to handle a broad range of judicial areas within the Norwegian system as well as a broad range of measures and professional competencies in order to assist the clients. Thus, the new one stop shops are expected to handle a complex set of tasks.

When the managers and employees were interviewed about their experience with the first phase of the reform, they expressed a sort of ambivalence towards the high degree of freedom and openness provided by the central authorities concerning the implementation of the reform. One of the managers from a medium-sized shop claiming to follow a moderate 
integration model (neither weak nor strong) noted the following just subsequent to the opening of the shop:

[We experienced] being faced with just ideas and empty frames. We did not know how to find our way, or what to do, concretely in order to make things work. It was as we had developed this big shell but without any new content (excerpt from original transcript of interview with local front line employee).

Even though thee reform documents describe new routines and ideas concerning ways of working as well as identify possible interfaces between different functions and new work processes, the employees and managers at the local shops report that these rather concrete plans provide little instruction for how these are to be implemented in practice at the new shop: "In order to figure out how to work in the new way we had to develop this new content [i.e. the specifics of this new way of working]."

An employee of another medium-sized shop, this one following a radical generalist model, articulated the following situation:

We have to take what comes on our desk, learning by doing; we do not know what to do with the cases that dump down on our desk. We have been making routine descriptions; we have been working with specifying a new division of work, but I feel I am not able to make use of them. But still, we learn all the way (excerpt from original transcript of interview with local front line employee).

Thus, generally, the local actors expressed a large degree of frustration with the first phase of the reform. Even though a majority supported the initial reform idea and rationale (as it had 
been discussed among the professionals within the sector for years), many did not find the openness and invitation to participate in providing new solutions to how to enact the integration in practice adequate. This resulted in an expressed lack of confidence in the management.

In the second phase, content reform as well as the performance management system was introduced. This was received in various ways among the local managers and employees. The new legislation and types of social security funding were in general seen as providing more specific instructions of how to organize and perform the tasks (Andreassen et al., 2011). This will now be illustrated by taking a closer look at how the new system of funding and categorisation of clients was experienced as supporting the new institutional mission of the integrated organisation. One of the local managers described the new funding system, called $\mathrm{AAP}$, as follows, which is representative the general opinion among managers:
After AAP, I see our practice changing from case processing to supervision of clients. This entails a change of mentality where the professionals are incentivised to focus on what the clients' needs of practical support in terms of getting back to work rather than whether they have rights to specific kinds of financial support (excerpt from original transcript of interview with local managers).

Thus, the AAP provided new frames that could help the employees to redefine their way of assisting the clients. In addition, this reframing from clients' rights to their needs also provided the local shops with measures to differentiate between users who require complex services and users requiring more simplified services. This became a tool to differentiate between services aimed at tame-problem situations, requiring a standardisation of procedures, 
and services aimed at wicked problems requiring large amounts of deliberations and individual tailoring (Andreassen et al., 2011, p. 20).

Thus, the new system of social security funding (together with a new legislation and other measures coming with the content reform) can be characterised as a tool for the managers and employees of the local shops to employ, which concretely promoted the institutional change by incentivising a transition from a rights-oriented towards a needsoriented way of enacting the services. As one manager put in one of the reports:

What happens is not that the AAP and the tool for evaluation of clients' needs and capacity, are experienced as being pushed top-down on the local actors. Rather it appears like these new measures are creating opportunities for embarking on a new local development process, more focused towards a viable way of working (Klemsdal, 2011, p. 346).

However, the management-by-objective-system that was introduced at the same time was received less univocally. The introduction of the system was accentuated by a particular situation in which a strong critique in the public media faced the whole organisation accusing the new welfare administration of inability to support their clients, reporting about queues and unprocessed requests from clients (Breit, 2014). This made the central management emphasize the MBO -system as a tool for handling what they framed as a crises situation. Some of the interviewed local managers characterised the MBO as a useful tool for prioritizing the immense amount and complexity of the various tasks. Many, however, perceived it as an addition to the general high and complex workload; it focused the attention of the local managers towards set performance goals as in a tame problem situation and away from a focus on developing the services in order to address the wicked problems facing the 
shop and ultimately enacting the institutional change (Andreassen et al., 2011). The MBO system was, thus, not considered supportive for the overall purpose of the reform (Klemsdal, 2011). Several of the employees expressed doubt about whether the top managers understood the purpose of the reform at all; they expressed a lack of confidence in management due to misplaced exercise of authority.

The lesson from the second phase is that a little specification in terms of the tools provided by the content reform provided a balance between authority and openness that seemed to go a long way towards forming a basis for trust. In contrast, more commanding specifications of the MBO system tended to limit confidence and increase uncertainty in the situation.

\section{A Framework for Designing Trust Reforms: Minimal Critical Specification Design}

From the case analysis, some concrete illustrations can be extracted of the dynamics and complexity that encompass trust relations during the implementation of administrative reforms. Further, we can draw some lessons on the challenge of maintaining an optimal space for trust relations to evolve in terms of ensuring an optimal mix of uncertainty and confidence between the parties in the process through the exercising of the managerial measures of authority and openness.

As noted, the general goal of the reform gained initial support from the employees, which represented a basis (signals) for confidence between the parties. Furthermore, the top managers decided in the first phase to lower their guards and invited the local managers and employees of the one stop shops to figure out the details of how to enact the reform on the basis of their local knowledge. Thus, they were opening a space for trust relations to unfold on the basis of mutual uncertainty. However, as the implementation process unfolded, the local managers and employees experienced too much uncertainty, and they had little to hold 
on to in order to navigate and grapple with the new situation. The general goal formulations of an integrated service as well as ideas about the new one stop shops-such as the demand of co-location of the three former services, as well as general ideas about 'a holistic approach towards the individual users needs according to their life situation; as for instance formulated in the white paper from the parliament (St.prp., 46 2004-2005)—gave little direction or support in terms of how to get there. Thus, this openness in reform design ensuring a large degree of uncertainty can be interpreted as too weak a basis for confidence among the parties. The space for trust became too open, which led to spirals of distrust.

In the second phase, the content reform provided the local shops with more specific frames for reaching the goal of a new integrated service (such as providing services on the basis of needs rather than rights). The frames were experienced as tools for developing the practices within the shop in a way that resonated with the general formulations of the purpose of the reform. Thus, this can be interpreted as the content reform represented an adequate basis of confidence and provided a relative space for local experimentation and enactment and thus a degree of uncertainty, enough to allow trust relations to be at play.

However, the MBO system introduced parallel to the content reform and accentuated by the media crises did not have the same consequences. Specifying 50 performance goals but no development goals, this system was not helpful in the local development process at the one stop shop. Rather, the MBO system was described as turning the attention away from development and towards production, leaving the development process in the dark. They were, thus, not considered as constructive specifications for the implementation of the administrative reform, suggesting that they were not inducing confidence among the parties.

These reflections - extrapolated from the analysis of the experiences from the two different phases of the implementation of the NAV reform - show that maintaining trust relations during implementation of public reforms is about comprising a right balance 
between leeway for participation in enacting the reform at the local level and an adequate amount of authority in terms of specification. This balance, however, can probably never be settled. It must be enacted actively, as with any kind of balancing act that requires proactive movement to succeed. This process can, thus, not easily be put into a formula. Rather, this paper uses a heuristic or a sensitizing concept (Blumer, 1954) that highlights this balancing act in a way that may be useful for the designer and manager of the implementation of reform plans. This heuristic draws on the notion of 'minimal critical specification design' —a term that was initially coined by Philip Herbst (1974)—on the basis of empirical experiences from the Norwegian industrial democracy experiments that were conducted during the 1960s and 70s (Klemsdal, Ravn, Amble and Finne 2017). The concept was initially coined to optimize the balance between managerial instructions and employee participation in order to underpin local processes of experimentation and learning to ensure situational fit (Klemsdal, 2013). As for the discussion of how reform plans and, thus, processes of implementation can be designed in order to accommodate positive processes of trust between managers and employees, the concept might be helpful because it highlights the importance of providing minimum specifications (rather than maximum) in order to ensure a certain degree of uncertainty and, thus, openness during the implementation process to allow trust relations to develop. But it still provides a minimum of critical specifications in order to secure direction and a shared focus as a basis for confidence during implementation. The lessons from the Norwegian welfare reform were that a minimal critical specification of the reform should come in tools rather than specific performance goals. Further the specifications should explicitly address and thus underpin, the local development process rather than the primary production process of the organization as such.

The notion of minimal critical specification design, thus, provides a heuristic for how to balance authority (instructions) and openness in various situations in order to maintain 
optimal conditions (in terms of a mix of uncertainty and confidence) for trust relations to unfold.

\section{Conclusion}

The goal of reforms is seldom about maintaining trust between management and employees per se; rather, it is often about maintaining trust towards the environment of public users and citizens (Rothstein, 2011). However, given that implementation of reforms is seldom straightforward and involves handling of wicked problems lacking straightforward solutions, the goal of the design of reform plans should have the maintenance of trust relations as a goal in order to facilitate successful implementation (Caiden, 1999). This paper's conceptual analysis and practical illustration of the conditions of maintaining and enhancing trust during implementation of administrative reforms suggest that since trust needs space to unfold by a dialectic of mutual returns between actors lowering their guard, reforms should be designed with regards to creating such a space, which is delimited by a balance between enacted authority and delegated leeway for employee involvement. This ensures an optimal mix of uncertainty and confidence among the parties according to the situational contingencies at hand. The theorizing and analysis, thus, illustrate that management by authority and management of trust should not be considered as opposite ends on a continuum. Rather, trust is a processual phenomenon that is enhanced in the balance between authority and openness. What management may perceive as trust-oriented actions towards employees, such as lowering their guards and inviting participation, does not necessarily promote trust; it must be balanced by more specified frames of instructions or specifications. The critical question is how to figure out the optimal balance. By drawing on Phillip Herbst (1974) notion of 'minimal critical specification design', this paper suggests a heuristics to frame specific 
attempts at reform designs, in which reforms are minimally but specifications and tools are given about how to implement them.

\section{Literature}

Alm Andreassen, T. (2012). Betingelser og beskrankninger for effektivisering. Belyst gjennom organisering av spesialiserte enheter for saksbehandling [Conditions for and Hindrances to Effectiveness], Nordiske organisasjonsstudier, 14(3), 30-42.

Alm Andreassen, T. \& K. Fossestøl. (2009). Å utvikle en helhetlig og brukerrettet forvaltning - Oppdragsstyring eller samstyring? [Developing a Holistic and User Centered Employment and Welfare Service], Tidsskrift for Velferdsforskning, 12(3), 168-79.

Alm Andreassen, T. \& K. Fossestøl. (2011). NAV ved et veiskille. Organisasjonsendring som velferdsreform [NAV at the Crossroads: Organizational Change as Welfare Reform]. Oslo: Gyldendal Akademisk.

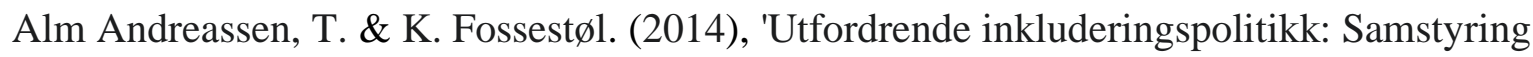
for omforming av institusjonell logikk i arbeidslivet, helsetjenesten og NAV [Governance for Transformation of Institutional Logic in Work Life, Health Services and NAV]', Tidsskrift for Velferdsforskning, 55(2): 174-202.

Alm Andreassen, T., K. Fossestøl \& L. Klemsdal. (2011), Gjør organisering en forskjell i praksis? Variasjoner i de lokale NAV-kontorenes organisering og konsekvenser for reformens måloppnåelse [Variations in the Organization of the Local NAV Offices], Nordiske organisasjonsstudier, 13(3), 9-13.

Andreasson, U. (2017). Trust—-the Nordic gold. Retrieved from Copenhagen: http://dx.doi.org/10.6027/ANP2017-737 
Axelrod, R. (1984). The evolution of cooperation. New York: Basic Books.

Bernstrøm, V. H., \& Svare, H. (2017). Significance of Monitoring and Control for Employees' Felt Trust, Motivation, and Mastery, 7(4). doi:10.18291/njwls.v7i4.102356

Bianco, W. T. (1994). Trust: Representatives and constituents. Ann Arbor: University of Michigan Press.

Blumberg, P. (1989). The predatory society: Deception in the American marketplace. New York: Oxford University Press.

Blumer, H. (1954). What is Wrong with Social Theory? American Sociological Review, 19(1), $3-10$.

Breit, E. (2014). Discursive practices of remedial organizational identity work: A study of the Norwegian Labor and Welfare Administration. Scandinavian Journal of Management, 30(2), $231-241$

Brown, P. G. (1994). Restoring the public trust. Boston: Beacon.

Caiden, G. E. (1999). Administrative reform—Proceed with caution. International Journal of Public Administration, 22(6), 815-832. doi:DOI: 10.1080/01900699908525406

Christensen, T., Fimreite, A. L., \& Lægreid, P. (2014). Joined-Up Government for Welfare Administration Reform in Norway. Public Organization Review, 14(4), 439-456. doi:10.1007/s11115-013-0237-8

Christensen, T., Lise Fimreite, A., \& Lægreid, P. (2007). Reform of the employment and welfare administrations - he challenges of co-coordinating diverse public organizations. International Review of Administrative Sciences, 73(3), 389-408. 
doi:10.1177/0020852307081149

Christensen, T., \& Lægreid, P. (2013). Welfare Administration Reform Between Coordination and Specialization. International Journal of Public Administration, 36(8), 556-566. doi:10.1080/01900692.2013.772628

Clark, M. C., \& Payne, R. L. (1997). The nature and structure of workers' trust in management. Journal of Organizational Behavior, 18(3), 205-224.

doi:doi.org/10.1002/(SICI)1099-1379(199705)

Colquitt, J. A., Scott, B. A., \& LePine, J. A. (2007). Trust, trustworthiness, and trust propensity: A meta-analytic test of their unique relationships with risk taking and job performance. Journal of Applied Psychology, 92(4), 909-927. doi:10.1037/00219010.92.4.909

Deng, J., \& Wang, K. Y. (2009). Feeling trusted and loyalty: Modeling supervisorsubordinate interaction from a trustee perspective. The International Employment Relations Review, 15(1): 16-38.

Dirks, K. T., \& Ferrin, D. L. (2001). The role of trust in organizational settings. Organization Science, 12(4), 450-467. doi:10.1287/orsc.12.4.450.10640

duGay, P. (2000). In praise of bureaucracy: Weber, organization, ethics. Thousand Oaks, CA: Sage.

Elster, J. (2007). Explaining social behavior: More nuts and bolts for the social sciences. Cambridge: Cambridge University Press.

Falk, A., \& Kosfeld, M. (2006). The hidden costs of control. American Economic Review, 96(5), 1611-1630. doi:doi: 10.1257/aer.96.5.1611 
Feldheim, M. A. (2007). Public sector downsizing and employee trust. International Journal of Public Administration, 30(3), 249-270. doi:DOI: 10.1080/01900690601117739

Fossest $\varnothing 1$, K., Breit, E., Andreassen, T. A., \& Klemsdal, L. (2015). Managing institutional complexity in public sector reform: Hybridization in front-line service organizations. Public Administration, 93(2), 290-306. doi:10.1111/padm.12144

Grint, K. (2005). Problems, problems, problems: The social construction of 'leadership'. Human Relations, 58(11), 1467-1494. doi:10.1177/0018726705061314

Herbst, P.G (1974). Socio-technical design: Strategies in multidisciplinary research. London: Tavistock Publications, 1974.

Kahneman, D., Knetsch, J., \& Thaler, R. (1986). Fairness and the assumptions of economics. Journal of Economics and Finance (59), 285-300.

Klemsdal, L. (2009). Utviklingsprosessen på de lokale Nav-kontorene: Veien fra reform til ny praksis. Tidsskrift for velferdsforskning, 12(3), 180-191.

Klemsdal, L. (2011). Navet i reformprosessen: Den lokale NAV-lederen som utviklingsleder. In T. A. Andreassen \& K. Fossestøl (Eds.), NAV ved et veiskille. Organisasjonsendring som velferdsreform Oslo: Gyldendal Akademisk.

Klemsdal, L. (2013). From bureaucracy to learning organization: Critical minimum specification design as space for sensemaking. Systemic Practice and Action Research, 26(1), $39-52$.

Klemsdal, L., Ravn, J. E., Amble, N., \& Finne, H. (2017). The organization theories of the industrial democracy experiments meet contemporary organizational realities. Nordic Journal of Working Life Studies, 7(S2), 1-15. doi: https://doi.org/10.18291/njwls.v7iS2.96687 
Knack, S., \& Zak, P. J. (2003). Building trust: Public policy, interpersonal trust, and economic development. Supreme Court Economic Review, 10, 91-107.

Lau, D. C., Lam, L. W., \& Wen, S. S. (2014). Examining the effects of feeling trusted by supervisors in the workplace: A self-evaluative perspective. Journal of Organizational Behavior, 35(1), 112-127. doi:doi:10.1002/job.1861

Lewis, D., \& Weigert, A. (1985). Trust as a social reality. Social Forces, 63(967-985).

Luhmann, N. (1979). Trust and power. New York: Wiley.

Luhmann, N. (1988). Familarity, confidence, trust: Problems and alterantives. In D. Gambetta (Ed.), Trust making and breaking cooperative relations (pp. 94-107). New York: Blackwell.

Miller, G. J. (1992). Managerial dilemmas: The political economy of hierarchy. Cambridge, UK: Cambridge University Press.

Morgan, D., \& Zeffane, R. (2003). Employee involvement, organizational change and trust in management The International Journal of Human Resource Management, 14(1), 55-75. doi:10.1080/09585190210158510

Powell, W. W. (1990). Neither market nor hierarchy: Network forms of organizations. In B. Staw \& L. Cummings (Eds.), Research in organizational behaviour. Greenwitch, CT: JAI Press.

Powell, W. W. (1996). Trust-based forms of governance. In R. M. Kramer \& T. Tyler (Eds.), Trust in Organizations: Frontiers of Theory and Research. Thousand Oaks: Sage

Putnam, R. (1993). Making democracy work. Princeton, NJ: Princeton University Press.

Rothstein, B. (2011). The quality of government. Chigago and London: The University of 
Chigago Press.

Sitkin, S. B., \& Roth, N. L. (1993). Explaining the limited effectiveness of legalistic

“remedies" for trust/distrust. Organizational Science 4(3), 367-392.

doi:http://dx.doi.org/10.1287/orsc.4.3.367

St.prp. (46 2004-2005). Ny arbeids og velferdsforvaltning. The Norwegian Parliament: Oslo

Sørensen, O. H., Hasle, P., \& Pejtersen, J. H. (2011). Trust relations in management of change. Scandinavian Journal of Management, 27(4), 405-417.

doi:doi.org/10.1016/j.scaman.2011.08.003

Sørhaug, T. (2004). Managementalitet og autoritetens forvandling : ledelse i en kunnskapsфkonomi. Bergen: Fagbokforl.

Tyler, T. R., \& Dawes, R. (1993). Fairness in groups: Comparing the self-interest and social identity perspectives. In B. Mellers \& J. N. Baron (Eds.), Psychological perspectives on justice: Theory and applications. Cambridge, UK: Cambridge University Press.

Tyler, T. R., \& Lind, E. A. (1992). A relational model of authority in groups. Advances in Experimental Social Psychology, 25, 115-191. doi:http://dx.doi.org/10.1016/S0065$\underline{2601 \% 2808 \% 2960283-X}$

Westin, A. F. (1992). Two key factors that belong in a macroergonomic analysis of electronic monitoring: Employee perceptions of fairness and the climate of organizational trust or distrust. Applied Ergonomics, 23(1), 35-42. doi:https://doi.org/10.1016/0003-6870(92)90008-

Williamson, O. E. (1993). Calculativeness, trust, and economic organization. Journal of Law and Economics, 36(1), 453-502. doi: http://dx.doi.org/10.1086/467284 
